\title{
A Convenient RP-HPLC Method for Assay Bioactivities of Angiotensin I-Converting Enzyme Inhibitory Peptides
}

\author{
Wei Wang, ${ }^{1}$ Nan Wang, ${ }^{2}$ Yu Zhang, ${ }^{1}$ Zheng Cai, ${ }^{1}$ Qihe Chen, ${ }^{3}$ and Guoqing $\mathrm{He}^{3}$ \\ ${ }^{1}$ Institute of Quality Standards for Agriculture Products, Zhejiang Academy of Agricultural Science, Hangzhou 310021, China \\ ${ }^{2}$ College of Biology and Environmental Engineering, Zhejiang Shuren University, Hangzhou 310015, China \\ ${ }^{3}$ Departmentof Food Science and Nutrition, Zhejiang University, Hangzhou 310058, China
}

Correspondence should be addressed to Guoqing He; gqhe@zju.edu.cn

Received 12 May 2012; Accepted 24 July 2012

Academic Editors: H. S. Garcia and J. Jia

Copyright (C) 2013 Wei Wang et al. This is an open access article distributed under the Creative Commons Attribution License, which permits unrestricted use, distribution, and reproduction in any medium, provided the original work is properly cited.

\begin{abstract}
A convenient and accurate reversed-phase high-performance liquid chromatography (RP-HPLC) method for angiotensin Iconverting enzyme inhibitory peptides assay was described in this paper. The mobile phase consisted of $70 \%$ A $(0.05 \%$ TFA and $0.05 \%$ triethylamine in water, $\mathrm{pH}=2.9-3.3)$ and $30 \% \mathrm{~B}(100 \%$ acetonitrile $)$ using an Isogradient program. The flow rate was $0.5 \mathrm{~mL} / \mathrm{min}$. The absorb wavelength was $226.5 \mathrm{~nm}$; the column temperature was controlled at $25^{\circ} \mathrm{C}$. This method for angiotensin I-converting enzyme inhibitory peptides assay was convenient for the Iso-gradient program. The accuracy of the RT-HPLC method was verified by analyzing ACE inhibitory activity of the hydrolysate peptides of silkworm pupae protein, and the results showed that the RT-HPLC method was available for exploring new source of angiotensin I-converting enzyme inhibitory peptides rapidly and veraciously.
\end{abstract}

\section{Introduction}

Angiotensin-converting enzyme (ACE) is a di-peptidyl carboxypeptidase (EC 3.4.15.1) associated with the blood pressure regulation system of renin-angiotensin. This enzyme can increase blood pressure by converting decapeptide angiotensin I into potent vasoconstricting octapeptide angiotensin II, which leads to a consistent increasing of blood pressure. ACE has been recognized as critical in the renin-angiotensin-aldosterone system (RAAS) for leading to hypertension [1].

Over the last reports, the first ACE peptide inhibitor was discovered from snake venom due to its significant effects on the hypertension. Afterwards, more and more potent synthetic inhibitors of ACE, such as captopril and enalapril, were found continuously. Currently, the application of ACE peptide inhibitors has become an important way to cure hypertension, congestive heart failure (CHF), and chronic renal disease [2], but its side effects to the health are also noticeable [3]. Therefore, the bioactive peptides with ACE inhibitory activity were paid more and more attentiones because of their curative and nontoxic characteristics, especially the food-derived ACE inhibitory peptides, isolated from food or enzymatic digestion of food proteins, such as from gelatin [4], casein [5], fish [6], fig tree latex [7], $\alpha$ zein [8], cereals and legumes [9], fermented soybean food products [10], soy protein [11], edible mushrooms [12], and microbes [13] that have been successfully used. These anti-ACE peptides derived from food protein hydrolysates might be used as main ingredients of blood pressure-lowering functional foods and nutriments [14].

In order to facilitate the identification and isolation of peptides with anti-ACE properties and explore extensive source of peptides with ACE inhibitory activity, a convenient and accurate method for ACE inhibitory activity assay in vitro was developed in this paper.

At present, the method of Cushman and Cheung [15] was generally used to detect angiotensin I-converting enzyme inhibitory activity in vitro [1]. The principle of the method of Cushman and Cheung was ACE hydrolyzed substrate hippuryl- ${ }_{L}$-histidyl- ${ }_{L}$-leucine (HHL), then hippuric acid (HA) and histidyl-leucine (HL) was released, which could 
be extracted into ethyl acetate layer and detected at $228 \mathrm{~nm}$ [14]. However, the extraction was easily contaminated by HHL which was the weakness point of this method. Furthermore, other methods, such as fluorimetry [16-18], highperformance liquid chromatography (HPLC) $[19,20]$, and internally quenched fluorogenic methods [21], were quite complicated and exigent. Wu et al. [14] reported a direct HPLC analytical method and facilitated the assay of ACE inhibitory activity in some degree, but its elution conditions were gradient with several steps to adjust the elution conditions. This paper aims to set a RP-HPLC method with Iso-gradient elution conditions and explore the optimal quantity between HHL and ACE in the reaction system for getting a highest transform rate of HHL to HA. Furthermore, this novel RP-HPLC method is verified by analyzing the hydrolyzates of silkworm pupae protein.

\section{Materials and Methods}

2.1. Reagents. Angiotensin I-converting enzyme (0.25 U) and hippuryl- ${ }_{\mathrm{L}}$-histidyl- ${ }_{\mathrm{L}}$-leucine (HHL) were purchased from Sigma-Aldrich, USA. Hippuric acid (HA) and captopril were from Fluka, India. HPLC-grade trifluoroacetic acid (TFA), triethylamine (TTA), and acetonitrile were obtained from Tianjin Shield Company, China. Acidic protease (50000 U/g, Aspergillus usamii NO. 537) was from Wuxi enzymes of China. All other chemicals were of analytical grade.

2.2. Reagents Preparation for HPLC Analysis. HHL and ACE were dissolved in $100 \mathrm{mM}$ borate buffer $(\mathrm{pH}=8.3)$ supplemented with $300 \mathrm{mM} \mathrm{NaCl}$, and their concentrations were $5 \mathrm{mM}$ and $0.1 \mathrm{U} / \mathrm{mL}$, respectively. Meantime, HA and Captopril (standard ACE inhibitor) were dissolved in distilled water.

The reaction system: $10 \mu \mathrm{L}$ HHL, $10 \mu \mathrm{L}$ ACE, $40 \mu \mathrm{L}$ ACE inhibitors and $40 \mu \mathrm{L} 100 \mathrm{mM}$ borate buffer $(\mathrm{pH}=8.3)$. The system was incubated at $37^{\circ} \mathrm{C}$ for $30 \mathrm{~min}$, and then $250 \mu \mathrm{L} \mathrm{HCl}$ was added.

2.3. HPLC Analyze Conditions. The RP-HPLC system was consisted of a HPLC (2690 Waters, Milford, MA, USA) equipped with a Symmetry $C_{18}$ column $(4.6 \times 150 \mathrm{~mm}, 5 \mu \mathrm{m}$, Waters), 2996 photodiode array detector (DAD), system Instrument control, data collection, and Empower software of Waters Corporation.

The mobile phase was solvent A, 0.05\% TFA and 0.05\% triethylamine in water ( $\mathrm{pH}$ value at 2.9 3.3); solvent $\mathrm{B}, 100 \%$ acetonitrile; the ratio of solvent $\mathrm{A} /$ solvent $\mathrm{B}$ was $7 / 3$. The flow rate was $0.5 \mathrm{~mL} / \mathrm{min}$, and the injection volume was $10 \mu \mathrm{L}$. The elute was analyzed at a wavelength of $226.5 \mathrm{~nm}$, which was at the maximum absorbance of HA, and column temperature was maintain at $25^{\circ} \mathrm{C}$.

2.4. Protein Hydrolysate Preparation. The degreased dry silkworm pupae protein was hydrolyzed by acidic protease (50000 U/g, from Aspergillus usamii No. 537) at $35^{\circ} \mathrm{C}$ and $\mathrm{pH} 3.0$ for 5 hours in a protein concentration $10 \%$. Then the

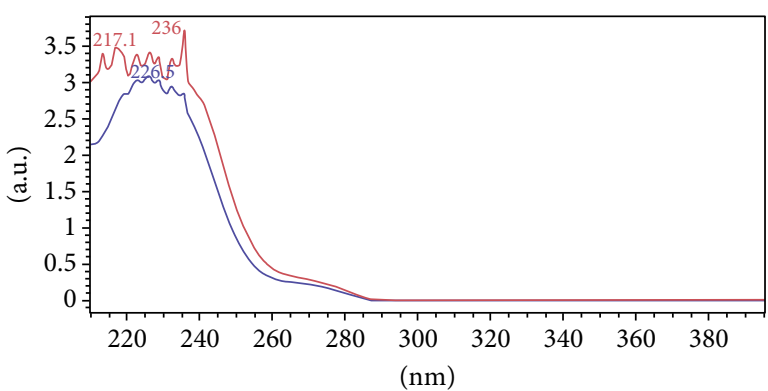

Figure 1: The ultraviolet absorbance spectra of HHL and HA.

solution was filted by $0.45 \mu \mathrm{m}$ nylon syringe filter. Then, the supernatant was freeze-dried for HPLC analysis.

2.5. The Principle of the Convenient RP-HPLC Method. The substrate HHL showed a wider absorbance from $217 \mathrm{~nm}$ to $236 \mathrm{~nm}$, and HA with the highest absorbance at $226.5 \mathrm{~nm}$. At the optimum separation condition of the two compounds, the inhibitory rate was calculated by $I \%=(A-B) / A \times$ $100 \%$; where $A$ was the peak area of HA without adding ACE inhibitors; $B$ was the peak area of HA with adding ACE inhibitors.

2.6. Statistical Analysis. Unless otherwise indicated, all data were average of three repeats, and data are presented as means \pm SEM. Two-way ANOVA and $t$-tests were employed in this paper, which were contained in SAS statistical analysis software, version 9.0 (SAS Institute, Cary, NC, USA).

\section{Results and Discussion}

3.1. Selection of Detectable Wavelength. $5 \mathrm{mM} \mathrm{HHL}$ and $1 \mathrm{mM}$ HA were detected at HPLC elution conditions as described in Section 2.3 from $210 \mathrm{~nm}-400 \mathrm{~nm}$, respectively. At $226.5 \mathrm{~nm}$, the absorbance of HA was the highest as shown in Figure 1 and HHL exhibited the wider absorbance from $217 \mathrm{~nm}$ to $236 \mathrm{~nm}$. The absorbance ratio of HA was increased $1.62 \%$ at $226.5 \mathrm{~nm}$ than $228 \mathrm{~nm}$, while the absorbance ratio of HHL was decreased $1.75 \%$ at $226.5 \mathrm{~nm}$ than $228 \mathrm{~nm}$. As a result, we employed $226.5 \mathrm{~nm}$ as the detectable wavelength of the following HPLC analysis (see Figure 1).

3.2. Separations of the Targets. Under the HPLC analytical conditions described in Section 2.3, the retention time of HHL and HA were $3.858 \mathrm{~min}$ and $4.602 \mathrm{~min}$, respectively. Figure 2 showed that $\mathrm{HHL}$ and $\mathrm{HA}$ were satisfactorily separated.

The separation rate was the separated level of the two borders upon peak; it was expressed as

$$
R=2 \frac{t_{\mathrm{RB}}-t_{\mathrm{RA}}}{W_{A}+W_{B}} .
$$

(Note: $R$ : resolution; $t_{\mathrm{RB}}$ : retention time of component $\mathrm{HA}$; $t_{\mathrm{RB}}$ : retention time of component HHL; $W$ : base line width of peak.) 


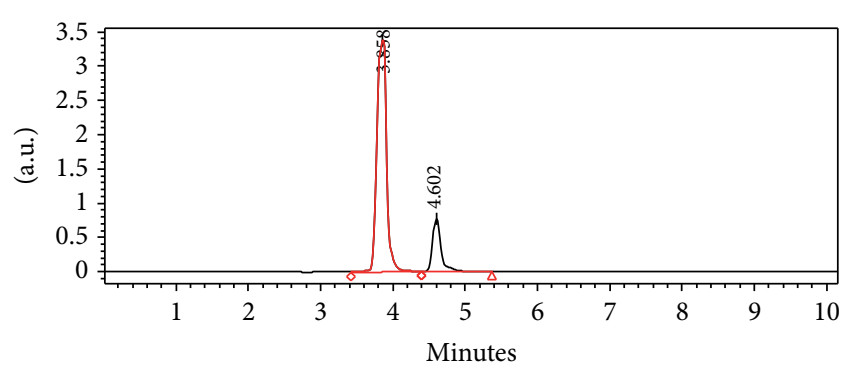

FIgURE 2: The separation result between HHL and HA by the RPHPLC conditions.

Figure 2 gave the result of " $R=1.48$," and $R=1$ means the two peaks were separated elementary, and $R=1.5$ means the two peaks were separated thoroughly. So, our results showed that the two targets had been separated satisfactorily (see Figure 2).

3.3. The Linearity and the Lowest Detect Capability. $1 \mathrm{mM}$, $0.5 \mathrm{mM}, 0.1 \mathrm{mM}, 0.05 \mathrm{mM}$, and $0.01 \mathrm{mM}$ concentrations of HA were prepared as the high concentration of standard criterion for the linearity analysis; $5 \mu \mathrm{M}, 1 \mu \mathrm{M}, 0.5 \mu \mathrm{M}$, $0.1 \mu \mathrm{M}$, and $0.05 \mu \mathrm{M}$ concentrations of HA were used as the middle concentration of standard criterion for the linearity analysis; $0.1 \mu \mathrm{M}, 0.05 \mu \mathrm{M}, 0.01 \mu \mathrm{M}, 0.005 \mu \mathrm{M}$ and $0.001 \mu \mathrm{M}$ were employed as lowest concentrations of standard criterion for the linearity analysis.

The results of the linearity analysis at the high concentration was $y=11947 x+1173.5, R^{2}=1$; at middle concentration linearity: $y=11497 x+3886.3, R^{2}=1$; at the lowest concentration: $y=45563 x+452.7, R^{2}=0.939$; at the concentration of $0.01 \mu \mathrm{M}$, the linearity of peak area and concentration was accorded to the equation very well, while at the concentration of $0.005 \mu \mathrm{M}$, the peak area began to deviate the equation. So, the lowest detect capability of this HPLC method was considered as $0.005 \mu \mathrm{M}$.

The method of Wu et al. [14] gave a linearity of HA from $0.01 \mathrm{mM}$ to $1.0 \mathrm{mM}\left(y=1 \times 10^{7} x+1801.1, R^{2}=0.9998\right)$, but did not provide the lowest detect capability of the method. Also, the HA concentrations used in their method were in the high concentration linearity scope, but in fact, the linearity of middle and lowest concentrations was more valuable for ACE inhibitor assay.

3.4. Recovery Rate and Precision Effect. In order to detect the recovery rate, we used the method of sample recovery test. $5 \mathrm{mM}, 2.5 \mathrm{mM}$, and $1 \mathrm{mM}$ captopril were used as ACE inhibitors, and the HA concentration was detected in our HPLC conditions in the reaction system. $20 \mu \mathrm{M}$ HA was added to the reaction system, and the HA concentration was analyzed by HPLC again. The result of the recovery rate we got was $99.70 \%-100.46 \%$, and the Relative Standard Deviation (RSD) was $0.38 \%(n=9)$.

Otherwise, the HA concentrations of HHL and ACE reaction systems without ACE inhibitors were analyzed 9 times in three days, and the RSD result was $0.33 \%$. The analysis of the HA peak area of these 9 times showed that

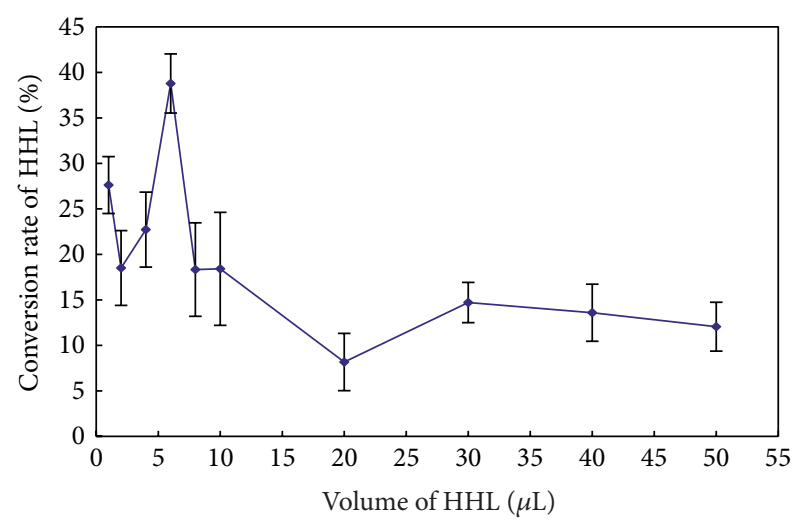

FIGURE 3: The effect of HHL concentration on the conversion rate from HHL to HA.

there was no significant difference among them $(P<0.001)$. This proved that the method was precise and steady.

3.5. The Optimal Quantity Relationships between HHL and $A C E$. The selectivity and sensitivity were very important to the assaying method [22]. At the same time, other reaction conditions, such as $\mathrm{Km}$, also affected the performance of the assay, because the method principle was based on the conversion rate of HHL to HA catalyzed by ACE. In this paper, the incubation time and temperature followed the values of Cushman and Cheung [15], and this method focused on the substrate transform rate from HHL to HA in different concentrations of HHL with a fixed concentration of ACE.

The total reaction volume was $100 \mu \mathrm{L}$, including $10 \mu \mathrm{L}$ ACE in a concentration of $0.1 \mathrm{U} / \mathrm{mL}$, different volume of HHL $(1 \mu \mathrm{L}, 2 \mu \mathrm{L}, 4 \mu \mathrm{L}, 6 \mu \mathrm{L}, 8 \mu \mathrm{L}, 10 \mu \mathrm{L}, 20 \mu \mathrm{L}, 30 \mu \mathrm{L}, 40 \mu \mathrm{L}$, $50 \mu \mathrm{L})$ in a concentration of $5 \mathrm{mM}$, and the other volume of the system was filled up by $100 \mathrm{mM}$ borate buffer $(\mathrm{pH}=$ 8.3). The reaction system was incubated at $37^{\circ} \mathrm{C}$ for $30 \mathrm{~min}$, and $250 \mu \mathrm{L} \mathrm{HCl}$ was added, and then the HPLC assay was performed.

Figure 3 showed that, when the volume of HHL was $6 \mu \mathrm{L}$, the HHL to HA was at the highest conversion rate $38.78 \%$, and with the volume increasing of HHL, the conversion rate was decreased, which proved that accurate substrate quantity was helpful for improving the sensitivity of the HPLC method. When the HHL was $6 \mu \mathrm{L}$, the HA concentration was $0.01119 \mathrm{mM}$, higher than $0.01 \mathrm{mM}$ in the high concentration linearity which we got at the "linearity and lowest detect capability" section, and it was far higher than the lowest detection capability of the method we got. Thus, an optimal quantity relationship between HHL and ACE was $6 \mu \mathrm{L} \mathrm{HHL}$ in concentration of $5 \mathrm{mM}$ to $10 \mu \mathrm{L}$ ACE in a concentration of $0.1 \mathrm{U} / \mathrm{mL}$; the amount in this method was far lower compared to the sample preparation conditions for HPLC analysis described by $\mathrm{Wu}$ et al. [14], who reported the total reaction volume was $70 \mu \mathrm{L}$, made up of $50 \mu \mathrm{L}$ of $2.17 \mathrm{mM} \mathrm{HHL}, 10 \mu \mathrm{L}$ of $2 \mathrm{mU}$ of ACE, and $10 \mu \mathrm{L}$ of different concentrations of ACE inhibitors. Because of the high sensitivity of this method, the usage of HHL could be economized. And it was rapid and 
TABLE 1: Recoveries of HA in reaction with different concentrations of captopril $(n=9)$.

\begin{tabular}{lcccc}
\hline Captopril & Original $/(\mu \mathrm{M})$ & Adding $\mathrm{HA} /(\mu \mathrm{M})$ & Total $(\mu \mathrm{M})$ & Recovery rate $(\%)$ \\
\hline $5 \mathrm{mM}$ & $2.210 \pm 0.012$ & 20 & $22.143 \pm 0.011$ & 99.70 \\
$2.5 \mathrm{mM}$ & $3.713 \pm 0.009$ & 20 & $23.821 \pm 0.014$ & 100.46 \\
$1 \mathrm{mM}$ & $6.427 \pm 0.016$ & 20 & $26.441 \pm 0.007$ & 100.05 \\
\hline
\end{tabular}

All the assayed results were expressed as means \pm SEM.

convenient to facilitate the ACE inhibitory peptides research (see Figure 3).

3.6. The Verification of the Method with the Hydrolysates of Silkworm Pupae Protein. In order to verify the popularized potential in practice, we prepared silkworm pupae protein hydrolysates as ACE inhibitor and compared its ACE inhibitory activity with captopril (Table 1). The result showed that ACE inhibitory rate of hydrolyzates was $73.21 \pm 2.17 \%$ in the concentration of $2 \mathrm{mg} / \mathrm{mL}$, and inhibitory rate of captopril was $85.2 \pm 1.13 \%$ in the concentration of $5 \mathrm{mM}$.

Comparison to the previous methods [20], the HPLC method developed in this paper separated HHL and HA perfectly in a more complex system and reduced analytical time (Figure 1). The advantages of this method are perhaps due to the different mobile components. In our study, the $\mathrm{pH}$ value of mobile phase was maintained at 2.9 3.3 with $0.05 \%$ TFA and $0.05 \%$ TTA in water. Different ratios of TFA and TTA will lead to the $\mathrm{pH}$ value deviate $2.9 \sim 3.3$ the peak shape and separate rate of HHL and HA will be not ideal it showed the $\mathrm{pH}$ plays an important role in the system for RP-HPLC assay. The Iso-gradient elution time applied in our method was $10 \mathrm{~min}$, which is longer than HA retention time $4.735 \mathrm{~min}$ the purpose was to elute the residues in the column more cleaner.

\section{Conclusion}

The HPLC assay described in this paper was a rapid, sensitive, and convenient method to determine the inhibitory activity on ACE. The results showed that HHL and HA could be separated completely with Iso-gradient elution program the assay effect and the lowest detection capability were improved, compared to the other methods. Also, this method skipped the extraction step of HA into ethyl acetate, which was indispensable in the method of Cushman and Cheung [15]. The results showed that this HPLC method could be used to explore new source of angiotensin I-converting enzyme inhibitory peptides rapidly and veraciously.

\section{Abbreviations}

HHL: Hippuryl- ${ }_{\text {L }}$-histidyl- ${ }_{\text {L }}$-leucine;

HA: Hippuric acid;

ACE: Angiotensin I-converting enzyme;

TFA: Trifluoroacetic acid;

TTA: Triethylamine;

HPLC: High-performance liquid chromatography;

DAD: Photodiode array detector;

RAAS: Renin-angiotensin-aldosterone system.

\section{Authors' Contribution}

The authors Dr. W. Wang and Dr. N. Wang contributed equally to this work.

\section{Acknowledgments}

This work was supported by the Zhejiang Provincial Natural Science Foundation of China (Y3090026) and National Natural Science Foundation of China (31101390).

\section{References}

[1] V. Vermeirssen, J. Van Camp, and W. Verstraete, "Optimisation and validation of an angiotensin-converting enzyme inhibition assay for the screening of bioactive peptides," Journal of Biochemical and Biophysical Methods, vol. 51, no. 1, pp. 75-87, 2002.

[2] R. Behnia, A. Molteni, and R. Igić, "Angiotensin-converting enzyme inhibitors: mechanisms of action and implications in anesthesia practice," Current Pharmaceutical Design, vol. 9, no. 9, pp. 763-776, 2003.

[3] F. H. Messerli, "Combinations in the treatment of hypertension: ACE inhibitors and calcium antagonists," American Journal of Hypertension, vol. 12, no. 8, pp. S86-S90, 1999.

[4] M. A. Ondetti and D. W. Cushman, "Enzymes of the reninangiotensin system and their inhibitors," Annual Review of Biochemistry, vol. 51, pp. 283-308, 1982.

[5] A. Morigiwa, K. Kitabatake, Y. Fujimoto, and N. Ikekawa, "Angiotensin converting enzyme-inhibitory triterpenes from Ganoderma lucidum," Chemical and Pharmaceutical Bulletin, vol. 34, no. 7, pp. 3025-3028, 1986.

[6] K. Sugiyama, K. Takada, M. Egawa, I. Yamamoto, H. Onzuka, and K. Oba, "Hypertensive effect of fish protein hydrolysate," Nippon Nogeikagaku Kaishi, vol. 65, pp. 35-41, 1991.

[7] S. Maruyama, S. Miyoshi, and H. Tanaka, "Angiotensin Iconverting enzyme inhibitors derived from Ficus carica," Agricultural and Biological Chemistry, vol. 53, no. 10, pp. 2763-2767, 1989.

[8] S. Miyoshi, H. Ishikawa, T. Kaneko, F. Fukui, H. Tanaka, and S. Maruyama, "Structures and activity of angiotensin-converting enzyme inhibitors in an alpha-zein hydrolysate," Agricultural and Biological Chemistry, vol. 55, no. 5, pp. 1313-1318, 1991.

[9] M. R. Rhyu, Y. J. Nam, and H. Y. Lee, "Screening of angiotensin converting enzyme inhibitors in cereals and legumes," Food Biotechnology, vol. 5, pp. 334-337, 1996.

[10] Z. I. Shin, R. Yu, S. A. Park et al., "His-His-Leu, an angiotensin I converting enzyme inhibitory peptide derived from Korean soybean paste, exerts antihypertensive activity in vivo," Journal of Agricultural and Food Chemistry, vol. 49, no. 6, pp. 3004-3009, 2001. 
[11] J. Wu and X. Ding, "Hypotensive and physiological effect of angiotensin converting enzyme inhibitory peptides derived from soy protein on spontaneously hypertensive rats," Journal of Agricultural and Food Chemistry, vol. 49, no. 1, pp. 501-506, 2001.

[12] D. H. Lee, J. H. Kim, J. S. Park, Y. J. Choi, and J. S. Lee, "Isolation and characterization of a novel angiotensin I-converting enzyme inhibitory peptide derived from the edible mushroom Tricholoma giganteum," Peptides, vol. 25, no. 4, pp. 621-627, 2004.

[13] Y. Nakamura, N. Yamamoto, K. Sakai, A. Okubo, S. Yamazaki, and T. Takano, "Purification and characterization of angiotensin I-converting enzyme inhibitors from sour milk," Journal of Dairy Science, vol. 78, no. 4, pp. 777-783, 1995.

[14] J. Wu, R. E. Aluko, and A. D. Muir, "Improved method for direct high-performance liquid chromatography assay of angiotensin-converting enzyme-catalyzed reactions," Journal of Chromatography A, vol. 950, no. 1-2, pp. 125-130, 2002.

[15] D. W. Cushman and H. S. Cheung, "Spectrophotometric assay and properties of the angiotensin-converting enzyme of rabbit lung," Biochemical Pharmacology, vol. 20, no. 7, pp. 1637-1648, 1971.

[16] J. Friedland and E. Silverstein, "A sensitive fluorimetric assay for serum angiotensin converting enzyme," American Journal of Clinical Pathology, vol. 66, no. 2, pp. 416-424, 1976.

[17] E. Silverstein and J. Friedland, "Elevated serum and spleen angiotensin converting enzyme and serum lysozyme in Gaucher's disease," Clinica Chimica Acta, vol. 74, no. 1, pp. 21-25, 1977.

[18] A. Persson and I. B. Wilson, "A fluorogenic substrate for angiotensin-converting enzyme," Analytical Biochemistry, vol. 83, no. 1, pp. 296-303, 1977.

[19] H. M. Neels, S. L. Scharpe, and M. Van Sande, "Improved micromethod for assay of serum angiotensin converting enzyme," Clinical Chemistry, vol. 28, no. 6, pp. 1352-1355, 1982.

[20] M. T. Doig and J. W. Smiley, "Direct injection assay of angiotensin-converting enzyme by high-performance liquid chromatography using a shielded hydrophobic phase column," Journal of Chromatography B, vol. 613, no. 1, pp. 145-149, 1993.

[21] M. C. Araujo, R. I. Melo, E. Del Nery et al., "Internally quenched fluorogenic substrates for angiotensin I-converting enzyme," Journal of Hypertension, vol. 17, no. 5, pp. 665-672, 1999.

[22] C. J. van Platerink, H. G. M. Janssen, and J. Haverkamp, "Development of an at-line method for the identification of angiotensin-I inhibiting peptides in protein hydrolysates," Journal of Chromatography B, vol. 846, no. 1-2, pp. 147-154, 2007. 

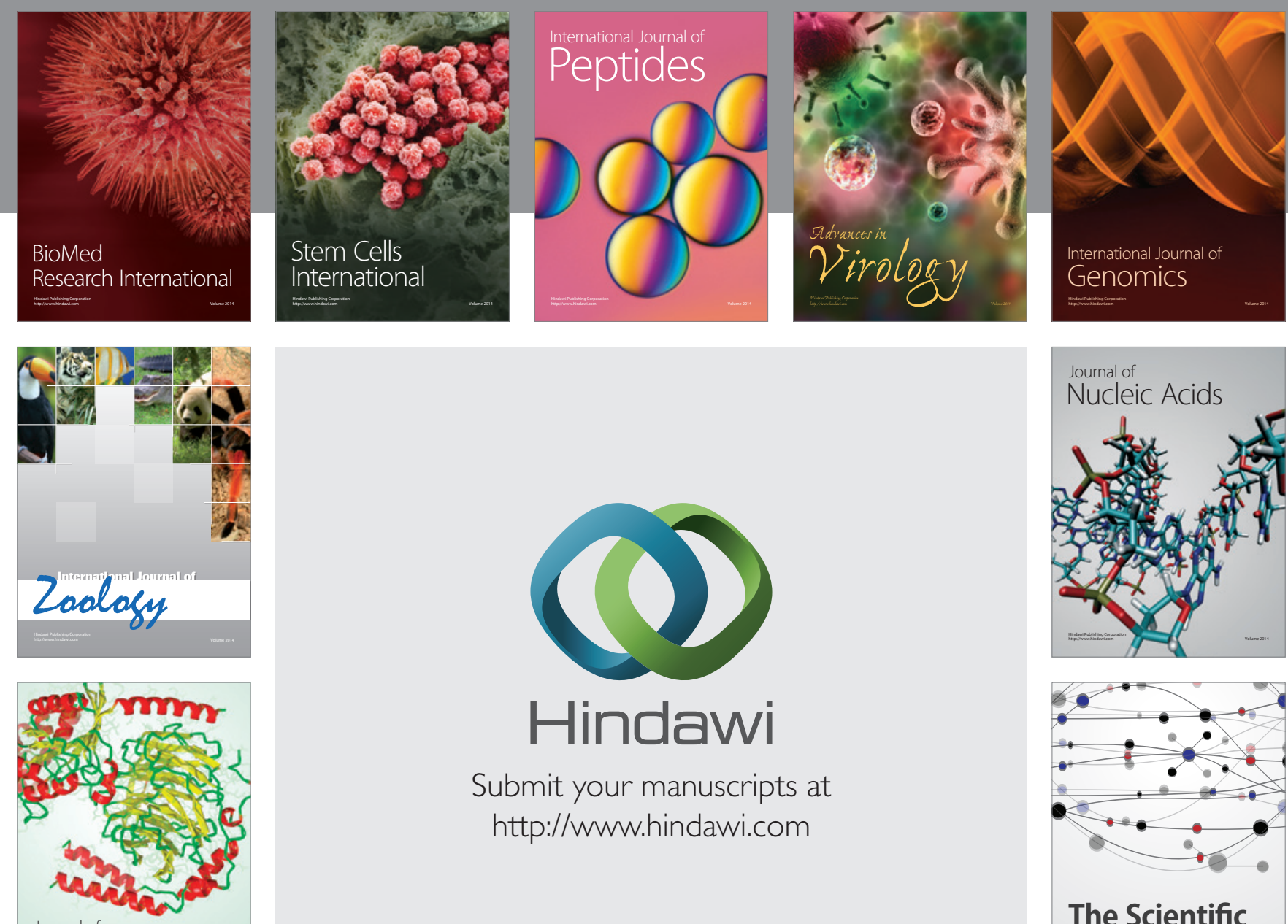

Submit your manuscripts at

http://www.hindawi.com

Journal of
Signal Transduction
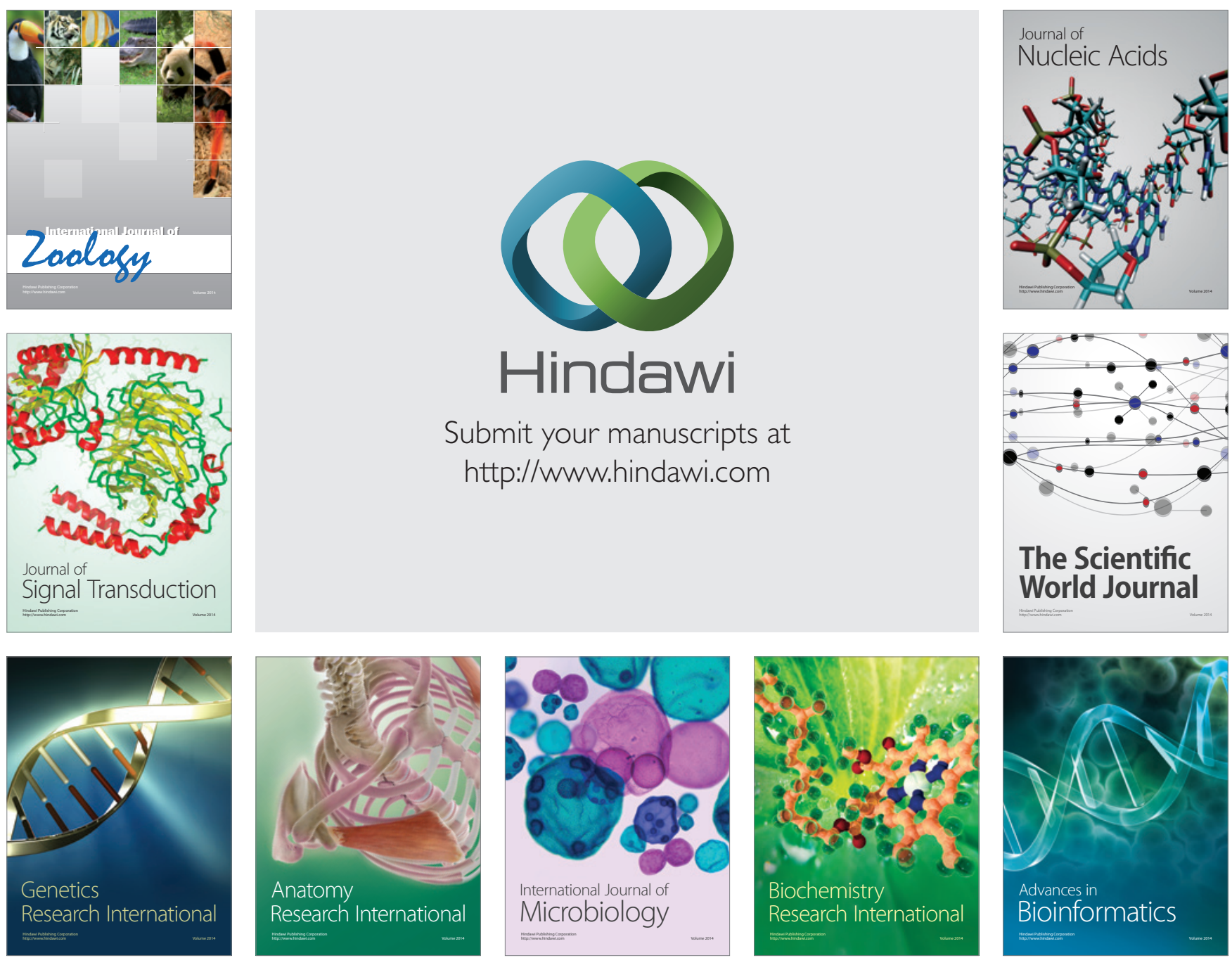

The Scientific World Journal
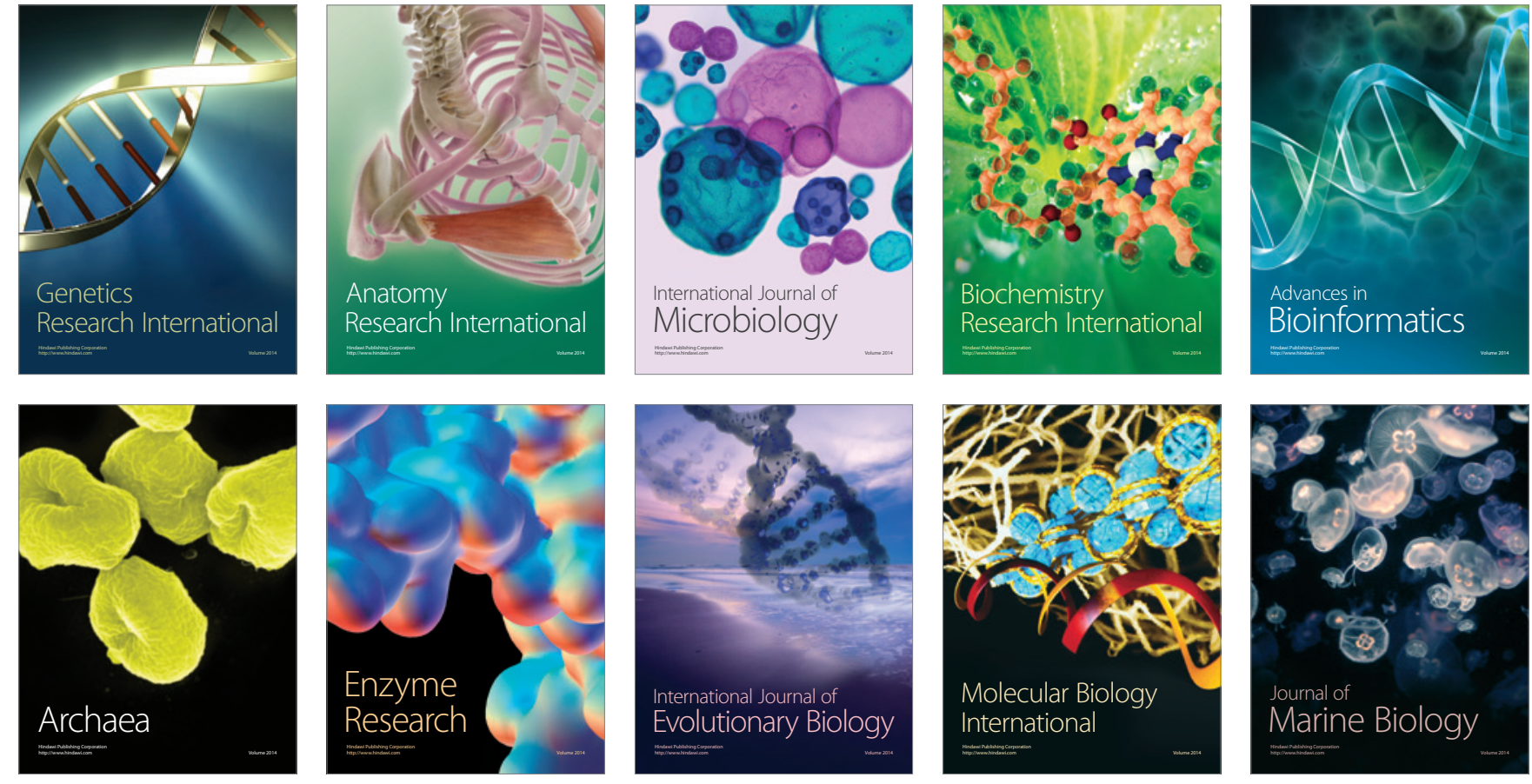